\title{
Etiek en kapitalisme
}

\author{
JP Labuschagne
}

\begin{abstract}
Ethics and capitalism

The main purpose of this essay is to demonstrate that, on the basis of Biblical Ethics, criticism on Marxism and Communism does not simultaneously imply adherence to Capitalism, for the most vulnerable point in Classical Capitalism is its lack of ethics as a leading principle. Since the days of Adam Smith, political economy (the common wealth of society) in Capitalism is metaphysically assumed, and in this sense derived, not from reality nor any proven ethical principle, but from a concept of a private economy (the competition of private greed) as a basis for society.
\end{abstract}

Dikwels word uit teologiese en kerklike kringe gewaarsku teen die ernstige gevare van die ideologie van die Marxisme en die kommunisme. Hierdie kritiek, mits dit objektief en gefundeerd voorgehou word, is vir die instandhouding van 'n vrye samelewing en in trou aan die Christelike etiek absoluut noodsaaklik. Waarteen egter gewaak moet word, is kritiek teen die kommunisme en Marxisme wat sonder meer neerkom op 'n pro-kapitalistiese standpunt; dit sou inderdaad die trou aan die Evangelie en die Christelike etiek ernstig in die gedrang bring. Die Kerk en dif gelowige kan immers nooit enige ideologie onvoorwaardelik ondersteun nie en die Christelike etiek mag hom ook nooit laat beroof van sy rol om geregtigheid voor te skrywe en elke saak en in elke situasie te beoordeel of dit goed of kwaad is nie. Wat verder deeglik besef moet word, is dat die etiek juis die groot probleem van die Klassieke Kapitalisme is.

Navorsing op ekonomiese terrein - hierop moet ons baie bedag wees - bevestig tot ' $n$ beduidende mate die waarheid van ' $n$ opmerking van Joan Robinson (in Galbraith 1974:11): 'Die doel van die bestudering van die ekonomie is nie om 'n klaargemaakte stel antwoorde op ekonomiese kwessies te bekom nie, maar om te leer hoe om dit te vermy om deur ekonomie bedrieg te word.'

Een van die talle abortiewe pogings om die etiek, vir openbare konsumpsie, te probeer versoen met Adam Smith se 'The wealth of nations' en so met die Klassieke Kapitalisme - kom uit die pen van Irving Kristol: 
Irving Kristol sê onder die opskrif "n Kapitalistiese konsepsie van geregtigheid':

Kapitalisme soos dit oorspronklik verstaan is deur Adam Smith was nie naastenby so 'n hartelose sisteem soos dit tot uitdrukking gekom het in die 19de eeu nie... Dit was die 19de eeuse kapitalistiese ekonomiese denke, met sy ongelooflike klem op die onmoontlikheid van die verbetering van die situasie van die arbeidersklas - terwyl verbetering inderdaad plaasgevind het - wat groot populariteit en aanvaarding verleen het aan die sosialistiese kritiek op die kapitalisme en die redistribusionistiese impuls wat sy verskyning begin maak het (in De George \& Pichler 1978: 60 \& 63 resp).

Kristol sê die kapitalisme ontwikkel in 'n verkeerde rigting wanneer Thomas Robert Malthus (1766-1834) en David Ricardo (1772-1823) afwyk van Adam Smith se basiese oogmerk, naamlik dat die kapitalistiese ekonomie gemoeid is met die produsering van welvaart en rykdom waardeur almal se lot verbeter sal word. Hulle laat die klem van die kapitalistiese ekonomie val op die verdeling van rykdom. Waar Smith gesê het almal kan hulle situasie verbeter, daar het Malthus gesê dat die situasie hopeloos was, minstens vir die laer klasse. Indien die laer klasse hulle welvaart verbeter, sê Malthus, sal hulle bevolkingsaanwas net sneller toeneem en alle welvaart verorber, sodat hulle spoedig net weer terug sal wees waar hulle begin het. Ricardo vervolg deur te sê dat die wêreld se groeiende bevolking uiteindelik nie gevoed sal kan word deur die beperkte landbougrond nie en in die lig hiervan was die armoedige situasie van die arbeiders op die lang termyn nie verbeterbaar nie. So, sê Kristol, het die skool van Malthus en Ricardo die volksmassas aanhoudend verseker dat hulle posisie nie verbeter kan word nie en dat hulle gedoem was om in armoede en ellende hulle bestaan te maak - hulle kon volgens hierdie skool alleen ' $n$ bydrae lewer deur minder kinders te hê en kuisheid te beoefen. Natuurlik sou die massas hierdeur ' $n$ afsku in die kapitalisme ontwikkel en hulle toevlug tot die sosialisme neem. (Wat Kristol nou nie gesê het nie, is dat die massas sekerlik nie net op woorde gereageer het nie, maar veel eerder op dit wat hulle aan die lyf ervaar het in bittere armoede, terwyl die rykes steeds in ' $n$ groeiende gaping ryker geword het, en hulle daarom, veral, hulle toevlug geneem het tot die sosialisme.) In hierdie situasie, sê hy, word herverdeling van rykdom 'n saak wat in toenemende mate aandag begin trek. 
Om die etiek ter sake te maak in Smith se 'The wealth of nations', probeer hy 'n brug slaan tussen dié werk en Smith se vroeëre 'The theory of moral sentiments'. In laasgenoemde werk, sê hy, het Smith aangetoon dat die hoogste menslike sentiment 'simpatie' was - 'die simpatie wat manne en vroue vir mekaar as menslike wesens het'. Kristol is oortuig dat hierdie simpatie van mens tot mens nog geld in 'The wealth of nations' en vervolg:

Hoewel Die rykdomme van die nasies 'n analise is van 'n ekonomiese sisteem gebou op eie-belang, het Adam Smith nooit vir 'n oomblik gedink dat mense bloot ekonomiese manne of vroue was nie ... Adam Smith het begryp dat mense in 'n gemeenskap lewe, en nie slegs in 'n ekonomie nie en dat hulle ' $n$ sin vir sosiale verpligting teenoor mekaar aanvoel ... (Kristol in De George \& Pichler 1978:60, 61).

Hoe Kristol nou ook al verder probeer aantoon het dat die rykes tog in hulle selfsugtige hantering van die ekonomie dinge doen wat die armes bevoordeel, en die rykes nie sonder welwillendheid teenoor die armes optree nie - bly alles steeds verval in 'n onoplosbare teenspraak: Niks pas in by die sisteem van 'Die rykdomme van die nasies' nie.

Smith se 'Teorie van die sedelike gevoel' van 1759 mak 'simpatie' (dit is die gemeenskapsgevoel) tot die grondslag van sy hele etiek. Hierin handhaaf Smith die selfversekerde standpunt dat die stem van die gewete slegs die weerklank is van dit wat andere oor ons oordeel. Nes Shaftesbury, het Smith,daarmee die stel van die morele oordeel van die handelende persoon verplaas op die medemens, die toeskouer van ons dade. Maar hierdie etiek, waarin wat ander oor ons dink, bepalend is vir ons eie optrede, reguleer beslis nie die dade van die selfsugtige en gierige individualis in Smith se 'Die rykdomme van die nasies' wat veel later in 1776 gepubliseer word nie. Smith het, minstens wat die ekonomie betref, in ' $n$ ander rigting ontwikkel as sy standpunt van 1759.

'Die rykdomme van die nasies' is gefundeer op die hebsugtige instinkte van die mens, en word vandaar uitgewerk as ' $n$ sisteem waarin die ekonomiese welsyn van almal reguleer word deur markkragte (aanbod en aanvraag) op die vrye mark - 'n mark wat vry is, nie net van owerheidsinmenging nie; maar ook van die regulering van die etiek, kerk of godsdiens. 'n Blote vae belofte van 'n algemene goed wat moet volg uit die kompetisie van die hebsugtiges, is nog geen inset wat deur die etiek gelewer word in die gang van die ekonomie en die 
samelewing nie - en 'n bietjie simpatie of welwillendheid van 'n ryke teenoor ' $n$ arme, by geleentheid, is nog minder ' $n$ wesenlike inset van die etiek. Al die mooi woordjies van 'n veronderstelde etiese figurering klop eenvoudig nie met so baie van Smith se uitsprake van wat werklik in die ekonomie geld nie:

'Dit is nie van die welwillendheid van die slagter... wat ons ons eetmaal verwag nie...'

'Die oorweging van sy eie private profyt is die enigste motief wat die eienaar van enige kapitaal lei om dit aan te wend...'

Smith het eenvoudig te veel verwag en as vanselfsprekend aanvaar wanneer hy sou reken dat die etiek in die samelewing en in die gang van die ekonomie tot sy reg kan kom wanneer hy sy siening van 'n private ekonomie (van wat voordelig is vir die hebsug van die individu) sonder modifikasie van toepassing maak op 'n politieke ekonomie ('n samelewingsekonomie waarin dit gaan om die welsyn van almal in die bevolking). Die kultuurhistoriese feite van die mense se reaksie op Smith se denke in die praktyk van die samelewing beaam hierdie inherente swakheid om die private ekonomie gelyk te maak aan die politieke ekonomie:

Die kapitaalkragtige hebsugtiges het enorme rykdomme in praktyk vermag uit hierdie sisteem in die samelewing - daarom is hulle prokapitalisties; die armes en die massas het ervaar dat hulle in die enorme vooruitgang in groeiende mate agtergeraak het - daarom is hulle anti-kapitalisties en dikwels selfs revolusionêr.

Om bloot met statistiese opportunisme te kom deur te sê dat armes nou beter salarisse het as voorheen, sê niks van die groeiende gaping tussen ryk en arm nie. Die praktiese akkumulasie van astronomiese rykdomme in min hande, terwyl die massa steeds worstel om 'n bestaan te maak, is die kwessie. Mooi propaganda-woorde kom nie hierby verby nie; wat uiteindelik met die oë gesien word en aan die lyf ervaar word in gebrek en frustrasie, het die laaste en beslissende sê (vgl De George \& Pichler 1978: 57-69).

Een van die leidende Westerse ekonome vandag, EF Schumacher, wat hom onderskei het in ontwikkelingstudies ten opsigte van die onder-ontwikkelende lande, skrywe dat dit tyd geword het om die dwaasheid van daardie befaamde filosofie raak te sien wat tot dusver ons ontwikkelingskonsep vergesel het (en in Adam Smith sy oorsprong het - na aanleiding van wat hierbo gesê is), naamlik: 'Wat die beste is vir die rykes moet ook die beste wees vir die armes' (Schumacher 1975: 139). 
Die teenspraak in Kristol se betoog konkretiseer uiteindelik in 'n totale platval van sy argument oor die plek van die etiek in die ekonomie, wanneer hy volstaan met die standpunt dat welvaart die beste versprei word deur die vrye markmeganisme, sonder inmenging deur die etiek, en 'n absolute wantroue te kenne gee in verbeteringsaksies wat die etiek in werking wil stel in die samelewing, insluitende die ekonomie, via die owerheidsmasjien. Alles voer na een konklusie: Dat hy - en ander kapitaliste wat soortgelyk redeneer - nie erns maak met die etiek nie. Hy sê:

Daar bestaan 'n groot aantal mense in die media, owerheid en die nie-wins-sektor wat oortuig is dat hulle beter weet as die mark hoe dinge verdeel behoort te word in ons samelewing... Terwyl hulle gebore is uit die middelklas, selfs in die geheel gesien uit welvarende agtergronde, is hulle net nie meer geinteresseer in geld nie, maar alleen geïnteresseer in mag, mag om die wêreld te verbeter, mag om dit ' $n$ beter plek te maak. Hoe gaan hulle hierdie mag in werking stel?... Hulle gaan die gesag van die owerheid gebruik om 'sosiale geregtigheid' te bereik. Ek sê nie dat hulle nie 'sosiale geregtigheid' sal vermag nie. Ek dink vir geen oomblik dat hulle daartoe in staat sal wees nie, maar ek kan dit nie bewys nie. Al wat ek kan sê is dat, in hulle pogings om dit te bereik, hulle hierdie liberale samelewing sal vernietig. Diegene wat enigsins omgee vir en hulle verbonde voel aan hierdie liberale samelewing, soos ek wel, sal nie hierdie pogings wat gemik is teen sy ondergang ewe vriendelik gadeslaan nie. Mens sal die gedagte om alles in ' $n$ beplande samelewing te omskep as bedreiging beskou....

Die gedagte van ' $n$ 'regverdige samelewing' wat op aarde bestaan is 'n stuk fantasie, 'n utopiese fantasie. Dis nie hoe lewe op aarde daar uitsien nie. Die rede lê daarin dat die wêreld vol is van mense wat anders is as ek en jy, en helaas, ons moet met hulle saamlewe ... en die punt van ' $n$ liberale samelewing en 'n markekonomie is om die verskille te aanvaar en te sê, 'Goed, bly jy wat $\mathrm{jy}$ is, en ek wat ek is. Ons sal verskil, maar ons sal saam besigheid doen ... ons sal nie noodwendig in vriendskap saamlewe nie, maar minstens in beskaafdheid teenoor mekaar... Ek sê nie dat kapitalisme 'n regverdige samelewing is nie. Wat ek sê is dat daar 'n kapitalistiese konsepsie van regverdigheid is wat ' $n$ werkbare konsepsie van regverdigheid is. 
Hierdie 'werkbare konsepsie' beteken vir Kristol en vele kapitaliste dat die vrye mark alle welvaart vir alle mense deur sy sogenaamde onpersoonlike werkkragte van aanbod en aanvraag moet bepaal. Daarmee word afgewyk van die poging hierbo om Adam Smith se vroeë beskouings oor 'simpatie' te probeer versoen met die vrye markmeganisme. Op die werklikheid van beperkte kompetisie en 'n blatante ekonomiese imperialisme van die kapitaalkragtiges in monopolie en kartel gaan hy eenvoudig nie in nie. Hy vervolg bloot: 'Enigeen wat aan jou ' $n$ regverdige samelewing op hierdie wêreld belowe, is ' $n$ bedrieër en 'n kwaksalwer. Ek is oortuig dat dit nie die aard van die menslike bestemming is nie....' In sulke absolute terme redeneer hy dat hy ook nie daarby kan uitkom om raak te sien dat alle mense die uitdaging het om daadwerklik - en hierin speel die etiek 'n vername rol - van hierdie wêreld ' $n$ beter plek vir almal te maak nie. Ten opsigte van ' $n$ Christen is hierdie uitdaging en etiek volledig gefundeer in gehoorsaamheid aan die God van die Bybel, en is hy daarop ingestel om hierdie geregtigheid in te dra in die lewe van mense (mikro-etiek), sowel as die strukture van die samelewing (makro-etiek). Dit is die Christen se trou aan die gang van God se koninkryk op aarde.

Voorts sê Kristol (in De George \& Pichler 1978: 67-69) van sy oortuiging van die onmoontlikheid van sosiale geregtigheid - wat net in absolute terme uiteindelik hanteer word:

Maar indien jy nie hierdie siening aanvaar nie, en indien jy werklik reken dat die lewe wel radikaal verskillend kan wees van wat dit is, indien jy werklik glo dat geregtigheid kan oorwin op aarde, dan sal jy waarskynlik begin om frases soos 'sosiale geregtigheid' baie ernstig op te neem en begin dink dat die funksie van die politiek daarin bestaan om die wêreld te bevry van sy euwels: om oorlog af te skaf, armoede af te skaf, diskriminasie af te skaf, afguns af te skaf.... Ons gaan nie een van daardie dinge afskaf nie.

Dis opvallend dat die tipiese liberalis-kapitalis in Kristol baie sterk na vore kom wanneer hy beslis deure wil toemaak sodat 'sosiale geregtigheid' buite die ekonomiese terrein bly - die etiek dus uit die ekonomie bly - waar dit op sosio-politieke terrein nog gangbaar mag wees. In praktyk werk liberalisme-kapitalisme so dat vryheid en regte uiteindelik deur kapitaal bepaal word - om die finale mag van kapitaal in die samelewing te behou, is die vrye mark noodsaaklik. Dis nie elke dag dat in die literatuur van die kapitalisme iets van hierdie dinge reguit 
gesê word deur 'n kapitalis self nie - gewoonlik moet die lesse van die geskiedenis dit in die feite van die werklikheid leer. Hy sê:

Gelykheid voor die wet en gelykheid ten opsigte van politieke regte is fundamenteel aan die liberalisties-kapitalistiese sisteem en, dis historiese feite, die ideologiese vaders wat die liberalismekapitalisme daargestel het, het almal geglo in gelykheid voor die wet en in een of ander vorm van gelykheid in politieke regte.

Die invoering van die term 'sosiale geregtigheid' verteenwoordig 'n poging om die idee van geregtigheid, wat versoenbaar is met die kapitalisme, verder te laat strek om ook ekonomiese gelykheid in te sluit. Voorstanders van wat 'sosiale geregtigheid' genoem word, wil ons oortuig dat ekonomiese gelykheid net soveel 'n reg is as gelykheid voor die wet en gelykheid ten opsigte van politieke regte... 'n Persoon wat glo in 'sosiale geregtigheid' is 'n gelykmaker. Ek sê nie dat hy of sy noodwendig glo in perfekte gelykheid nie; ek glo nie dat enigeen glo in perfekte gelykheid nie.

Maar 'sosiale geregtigheid' se voorstaanders is vreeslik behep met veel meer gelykheid as wat 'n kapitalistiese sisteem bereid is om toe te gee. Kapitalisme lewer baie goeie dinge op, maar, in die geheel gesien, is ekonomiese gelykheid nie een van hulle nie. Dit het nooit voorgegee om ekonomiese gelykheid daar te stel nie ... (in De George \& Pichler 1978: 57,58).

Gelyke geleenthede en gelyke inagneming van alle mense se belange, dit waarvoor die Christelike etiek ook staan, ook op ekonomiese terrein, kry eenvoudig nie die nodige aandag in die kapitalisme nie - soos die geval nou ook hier by Irving Kristol is. Daar moet gewaak word teen vergesogte veralgemenings dat die Westerse Sosialisme, of Sosiale Demokrasie, ten gunste sou wees van die letterlike gelykmaking van almal se salarisse en materiële besit - selfs Jean Jacques Rousseau praat van gelykheid in terme van 'n owerheidsfunksie wat uiterste materiële ongelykheid moet verhoed.

Daar is in kapitalistiese geledere tog ook 'n ander weg waarop meer openlik nie 'n versoening met die eise van die etiek voorgehou word nie in Adam Smith en die Klassieke Kapitalisme se vrye mark, wat, deur private hebsug gedrewe, veronderstel is om uit te kom by almal se welsyn. Een van die invloedrykste ekonome van die 20ste eeu in kapitalistiese geledere was John Maynard Keynes (1883-1946). Hy het in 1930 reeds opgemerk dat in hierdie periode, voor die kapitalisme se 
veronderstelde toekomstige wêreld waarin almal welvarend sal wees, daar voortgegaan sal moet word met die pretensie dat dit wat bedorwe is, goed is:

Maar wees gewaarsku: Die tyd vir al hierdie dinge het nog nie aangebreek nie. Vir minstens nog 'n honderd jaar moet ons aan onsself en alle ander mense voorgee dat die regverdige bedorwe is en dat dit wat bedorwe is, regverdig is; want wat bedorwe is, is nuttig en wat regverdig is, is nie.

Gierigheid en woeker en voorsorg moet vir nog 'n rukkie langer ons gode bly. Want hulle alleen kan ons uit die tonnel van ekonomiese noodsaak lei na die daglig (in Schumacher 1975: 19).

Die Britse Lord Keynes merk verder op dat dit nog nie tyd was nie vir 'n 'terugkeer na sommige van die vasste en sekerste beginsels van die godsdiens en die tradisionele deug - dat gierigheid 'n ondeug is, dat die afpersing deur woeker ' $n$ gruwel is, en dat die liefde vir geld veragtelik is (in Schumacher 1975: 24).

Keynes (in Schumacher 1975: 24) se raad is dat ekonomiese vooruitgang alleen moontlik is wanneer ons gebruik maak van daardie kragtige menslike meganismes van selfsug - dit wat godsdiens en die tradisionele wysheid in die algemeen verwerp en vra dat ons dit sal weerstaan.

Vanuit Sosiaal-Demokratiese geledere vra 'n eweneens wêrelderkende ekonoom, die Duitsgebore EF Schumacher in 1973 in hierdie verband of hierdie koers nie ' $n$ dreigende ondergang inherent daaraan het nie:

Die moderne ekonomie word aangedrywe deur 'n waansinnige gierigheid en het homself uitgegee aan 'n orgie waarin niks aan 'n ander gegun word nie, en hierdie is nie toevallige eienskappe nie, maar die spesifieke oorsake van sy ekspansionistiese sukses. Die vraag is nou of sulke oorsake op die lang duur effektief kan wees en of hulle nie in hulleself die spore van vernietiging dra nie (Schumacher 1975: 24,25).

Schumacher (1975: 19) sê dat Keynes se boodskap ons oë behoort oop te maak vir die feit dat die pad na die kapitalistiese hemel uitgeplavei is met slegte bedoelings:

In elk geval, die boodskap van Keynes is duidelik genoeg: Pasop! Etiese oorwegings is nie alleen bloot irrelevant nie, hulle is inder- 
daad 'n struikelblok, 'want wat bedorwe is, is nuttig en wat regverdig is, is nie'. Die tyd vir regverdigheid het nog nie aangebreek nie. Die pad na die hemel is uitgeplavei met slegte bedoelings.

Wat werklik vandag noodsaaklik geword het in die huidige samelewingskoers met sy steeds groeiende bedreiging van totale selfvernietiging in hom, sê Schumacher, is 'n nuwe lewenstyl wat, teenoor die sieklike, alles-bedreigende materialisme, ingestel is op permanensie.

Maar om enigsins te praat oor die moontlikheid van ' $n$ toekoms, verg nóu reeds drastiese beplanning en optrede. Wat in die ekonomie en industrie nodig is, is ' $n$ 'tegnologie met ' $n$ menslike voorkoms'. Wat nodig is, is ' $n$ samelewing wat in balans en harmonie kom met sy bodem en die hele natuurwerklikheid. Hy sê:

Ons moet nog leer om in vrede te lewe, nie alleen met ons medemens nie, maar ook met die natuur en, bowe-al, met daardie Hoër Magte wat die natuur gemaak het en ons gemaak het; want, verseker, ons het nie deur toeval tot bestaan gekom nie, en sekerlik ook nie onsself gemaak nie (Schumacher 1975: 17).

Schumacher (1975: 31, 32) vra: '... waar vind 'n mens die vermoë om die geweld van gierigheid, afguns, haat en hebsug in jouself te oorwin?' Hy het alleen een antwoord: 'n Lewende geloof in God. Vir hom as Christen is dit in geloof in die God van die Bybel. Hy sê:

In die etiek, soos op so baie terreine, het ons op roekelose wyse, en gewilliglik, afgesien van ons grootste klassieke Christelike erfenis. Ons het selfs daardie belangrike begrippe waarsonder etiese besinning nie vooruitgang kan hê nie, gedegradeer, begrippe soos deug, liefde, matigheid... Gevolglik is ons heeltemal onkundig, totaal onopgelei in daardie onderwerp wat, van alle denkbare onderwerpe, juis die belangrikste is. Ons het geen insig om mee te dink nie en is daarom maar te gereed om te glo dat die etiek ' $n$ veld is waar redenasie geen goed kan bereik nie... Dit is ons sentrale oortuigings wat in wanorde is en, solank as die huidige anti-metafisiese stemming volhou, sal die wanorde steeds erger word... Indien ons kan terugkeer na 'n edelmoedige erkenning van meta-ekonomiese waardes, sal ons landskappe weer gesond en mooi word, en ons mense sal weer die waardigheid van die mens terugwen, wat homself as hoër as die dier ken, 
maar nooit daardie noblesse oblige vergeet nie (Schumacher 1975: $82,83 \& 96$ resp).

Wanneer Schumacher ingaan op die etiek wat nodig geword het in ons tyd, dan antwoord hy dat dit nodig geword het om groot genoeg te wees, die moed te hê om die uitdaging te aanvaar, om weer terug te keer huis toe - soos in die Gelykenis van die Verlore Seun (Lukas 15: 11-32), en te leer van die geregtigheid van die Heer van die Bergpredikasie; hy sê:

... die Bergpredikasie gee inderdaad presiese instruksies hoe om 'n lewensuitkyk daar te stel wat kan lei na 'n ekonomie van Oorlewing... En dié wat huis toe kom is oortuig dat die rigting waarin die moderne tegnologie beweeg, en wat dit op voortgaande basis navolg - na steeds groter omvang, in groeiende tempo, en met steeds meer geweld, in verontagsaming van alle wette van natuurlike harmonie is - die teenoorgestelde is van vooruitgang. Daarom die oproep tot besinning en die soeke na 'n nuwe oriëntasie. Besinning dui daarop dat ons besig is om die fondamente van ons eksistensie te vernietig, en die reoriëntasie wil ons weer daartoe bring om te besef waaroor menslike lewe werklik gaan.

Op een of ander wyse sal elke mens kant moet kies in hierdie groot konflik. Om dit 'aan die deskundiges oor te laat', beteken om saam te gaan met die mense van die dolle stormloop. Dit word wyd aanvaar dat die politiek ' $n$ te belangrike saak is om oorgelaat te word aan deskundiges. Vandag is die kerninhoud van die politiek die ekonomie, en die kerninhoud van die ekonomie is die tegnologie. Indien politiek nie aan deskundiges oorgelaat kan word nie, kan ekonomie en tegnologie net so min aan hulle oorgelaat word (Schumacher 1975: $130 \&$ 131-132 resp).

In Schumacher het ons die ekonoom wat enersyds besef hoe noodsaaklik dit is dat die etiek in die ekonomie in werking gestel moet word en wat andersyds die ontdekking maak van 'n angswekkende leemte in die etiek: dat daar tans nie werklik in detail grondige etiese insig en rigtinggewing uitgewerk is ten opsigte van die samelewing, en die ekonomie veral, wat objektiewe wetenskaplikheid in toereikende mate kan oortuig of beïndruk dat dit in staat is om te lei na 'n prakties-sinvolle toekoms in die hier en nou nie. 
Ook die kerk het, wat hierdie etiek betref, iewers langs die pad van die geskiedenis uitgeval. John Kenneth Galbraith, 'n nuwe-geslag Amerikaanse ekonoom met 'n verligte neo-sosialisme, sê die kerk het tot en met die $17 \mathrm{de}$ eeu in Europa, 'deur sy kanonieke woordvoerders, bykans die monopolie oor kommunikasie met die massas gehad'.

Daarna, sê Galbraith (1974: 157), het die ekonomie die mag oor die kommunikasie met die massas oorgeneem: "n Oortuigende, miskien ietwat minder as algehele beheer oor die kommunikasie, van die kant van die beplanningsisteem, het in belang van sy produkte gelei na 'n vergelykbare moderne prestige vir ekonomiese instellings en die goedere en dienste wat hulle verskaf.'

Vandag, sê Galbraith, het die kerklike gesag grootliks afgeneem; daar bestaan net nie meer die groot godsdienstige figure van vroeër nie, en 'n sterk openbare instink beperk die hedendaagse predikant en priester tot temas wat nie sal lei tot kritiek op die samelewing en op 'private onderneming' in die ekonomie nie. Hy sê:

Die mag wat eenmaal ontleen is aan 'n Goddelike presensie - van 'n Persoonlikheid - bestaan nog; daar word elke dag op 'n wye front steeds respek daarvoor betoon... Maar selfs die vroomste mens sal erken, die visie het verflou, wanneer dit vergelyk word met die vroeëre gewaarwording daarvan (Galbraith 1984: 171).

Daarmee is dit duidelik genoeg hoe groot die taak en uitdaging van die kerk op die terrein van die samelewing, én die ekonomie, vandag werklik is.

Wat betref die sentrale argument oor die etiek en die Klassieke Kapitalisme, soos laasgenoemde sy oorsprong het in Adam Smith en vandaar verder ontwikkel het deur manne soos Malthus, Ricardo en John Stuart Mill (wat láát in sy lewe toenemend sosialisties geword het), kan ook verwys word na die baie eerlike standpunt wat hedendaags ingeneem word deur die Amerikaanse ekonoom, Paul A Samuelson, 'n erkende leidende figuur in die Westerse kapitalisme. Sonder om pretensies voor te hou asof die kapitalisme 'n etiese inslag sou hê, sê Samuelson (1976: 47) eenvoudig dat etiese kwessies iets is wat 'buite die werklike meganismes van die ekonomie' staan; die kapitalisme het nie 'n etiese inslag nie en begewe hom eenvoudig nie op die terrein van eties reg of verkeerd nie. Samuelson aanvaar, in die lig van hierdie standpunt, dat daar nogtans mense is op die ekonomiese terrein wat wel bereid is om op etiese gronde in te gryp op die markmeganisme met allerhande minimum en maksimum prysvlakke, en selfs ter wille 
van ' $n$ regverdiger dispensasie gewillig sal wees om die effektiwiteit, wat in die vrye markmeganisme ingebou is, in te kort sodat daar ' $n$ 'regverdiger' verdeling van inkomste sal wees. Hy verwoord hulle redes so:

Primêr, omdat die mens van effektiwiteit alleen nie kan lewe nie. Hy het belang by die vraag: Effektiwiteit waarvoor? En vir wie?... Die meeste van hierdie vloer- en plafonmaatreëls word daargestel in die naam van 'regverdigheid' - om ' $n$ bepaalde groep te help wat dit nodig het ten koste van 'n ander groep wat beskou word as baie welvarend en met meer as genoeg. Net soos Robin Hood 'die rykes beroof het om die armes te help' probeer hierdie maatreëls om 'n verdeling van reële inkomste te skep of te herstel wat as meer regverdig beskou word... Voorstanders hiervan is bereid om een of ander prys in die vorm van ' $n$ laer effektiwiteit te betaal ... Die ekonomiese wetenskap is nie by magte om 'n uitspraak te maak dat hulle noodwendig verkeerd is nie, mits hulle die koste in berekening bring (Samuelson 1976: 396).

Vir Samuelson is dit uitdruklik nie vir die ekonomie om uitspraak oor reg en verkeerd te maak ten opsigte van daardie dinge wat deur die etiek uitgemaak moet word nie. Die ekonomiese wetenskap het in hierdie verband alleen die taak om 'n aanduiding te gee van die kosteaspek verbonde aan sekere etiese beslissings wat gemaak mag word, sodat dit ook in berekening gebring mag word. Die etiese beslissing bly vir hom iets buite die kapitalistiese ekonomie.

Anders as die Klassieke Leissez Faire-Kapitalisme, wat die gang van die ekonomie volledig wil oorlaat aan die vrye gang van die markmeganisme (via aanbod en aanvraag) en in Milton Friedman 'n moderne woordvoerder het, is Samuelson en die moderne Neo-Klassieke Kapitalisme in die herverdeling van rykdom wel bereid tot indirekte owerheidsregulering van die proses van aanbod en aanvraag (wat opereer in 'n mark wat gedeeltelik perfek en gedeeltelik imperfek in sy kompetisie is) via fiskale en monetêre maatreëls.

Die instrumente van indirekte regulering word uitdruklik so ver moontlik beperk tot slegs fiskale en monetêre maatreëls. Hiermee word voortgebou op 'n weg van indirekte owerheidsregulering wat aanvanklik deur John Maynard Keynes geïnisieer is. Behalwe dat ekonome soos Schumacher en Galbraith met groot volledigheid daarop wys dat monetêre en fiskale maatreëls nie werklik die akkumulasie van groot rykdom in min hande stuit of die gaping tussen ryk en arm vernou nie, bly dit 
nogtans steeds so dat die etiek, anders as in die Westerse sosialisme, nie werklik as dominerende beginsel deel uitmaak van die ekonomiese meganisme nie. Samuelson (1976: 544) sê: 'Net soos die oerwoud sy reëls het, sonder inagneming van goed en kwaad, so het die kompeterende mark sy eie brute feite.'

In die wêreld van die kapitalisme bly die etiek nou eenmaal iets wat buite die ekonomie staan, as iets wat uitdruklik nie inpas by die veronderstelde effektiewe werking van die ekonomie nie. Selfs by die enkele kapitalistiese ekonome, soos Paul A Samuelson, wat teen die tipies pragmaties-liberalistiese vloedgolf in nog, hoewel baie indirek, tot ' $n$ mate inisiërende funksie aan die etiek in die samelewing sal vergun, is daar duidelik deurgaans geen moontlikheid van direkte toegang van die etiek tot die ekonomiese meganisme nie; daar kan alleen ' $n$ bydrae gelewer word vanuit die invloed wat die etiek moontlik mag hê op die owerheidsbeslissing wat via die owerheid se fiskale en monetêre maatreëls ' $n$ indirekte regulerende funksie op die vrye mark-meganisme uitoefen. In die Westerse sosialisme (of sosiale demokratiese denke) het die etiek wel direkte toegang tot die meganisme van die markekonomie omdat in hierdie ekonomie, afgesien van die prys wat dit mag kos, die vryheid van die mark minder belangrik is as die vryheid van die mens (beide individu en gemeenskap). In die sosialisme moet etiek en demokrasie die vryheid van die mens as hoogste doel waarborg. Die sosialisme sal byvoorbeeld op etiese gronde, met ' $n$ direkte ingrype van owerheidsweë op die markmeganisme, prysbeheer instel op sekere produkte, om die massa te beskerm teen te hoë inflasie waardeur hulle lewenspeil sterk afneem terwyl dié van die rykes skerp toeneem vanweë laasgenoemde se greep op en monopolisering van pryse en winste. Samuelson verkies in so ' $\mathrm{n}$ geval indirekte regulering van die mark, via fiskale en monetêre maatreëls, deur byvoorbeeld ' $n$ dempende invloed uit te oefen met verhoging van belasting of miskien rentekoerse of albei, om daarmee minder geld in omloop te stel. (Deur die teenoorgestelde te doen, word weer meer geld in omloop gestel en die mark gestimuleer.)

Milton Friedman wil geen direkte of selfs indirekte inisiatiewe van owerheidsweë op die vrye markmeganisme van toepassing maak nie; hy is oortuig dat die vrye kompeterende mark self geleidelik die nodige aanpassing sal maak, indien die vryheid daartoe gegun word, en dat dit die publiek minder sal kos.

Die Westerse sosialisme se kritiek teen die kapitalisme se bantering van die ekonomie in die algemeen (en dan geld dit ten opsigte van die 
standpunte van beide Samuelson en Friedman dus) is dat die armes en die massa finansieel deurgaans nadelig daardeur getref word, terwyl die posisie van die kapitaalkragtiges prakties steeds verbeter:

- Op 'n vrye markbasis, waar daar geen direkte owerheidsinmenging en kontrole plaasvind nie, stel groot kapitaal in 'n paar hande die massa en klein maatskappye altyd op 'n vlak van ongelyke geleenthede - die kapitaalkragtiges het dan eenvoudig vrye teuels om die lewe uit die massa te 'dreineer', en die massa het sonder owerheidsbeskerming net nie 'n kans nie (vgl Schumacher 1975: 60).

Groot kapitaal stel die ondernemer in staat om teen die groot maat wat hy aankoop, altyd ' $n$ beter aankoopprys te beding en uiteindelik ' $n$ groter profyt te bekom as die klein ondernemer - dit is wanneer hy nie reeds die bronne of produksie-instansie waarvan hy aankoop, besit nie. Wanneer hy die bronne of produksie-instansie besit, is hy natuurlik veel verder op die pad na beheer oor die mark en die prys van sy produkte. Groter kapitaal stel die groot ondernemer in staat om 'n groter mark te bekom, en deur groter markte groter winste, en stel hom tegelyk in 'n posisie om kleiner mededinging uit te skakel deur byvoorbeeld pryse laag te hou sodat die kleiner maatskappy, wat duurder aankoop, nie daarmee kan meeding en nog 'n wins maak nie. Wanneer kleiner maatskappye uitgeskakel is en beheer oor die prys bekom word, word die publiek benadeel met stygende pryse wat byvoorbeeld afgedwing kan word deur ' $n$ aanbod op die mark wat kleiner is as die aanvraag. Die massa het verder, weens sy geneigdheid tot 'n ooraanbod van sy betrokke arbeid, altyd 'n swakker bedingingsposisie ten opsigte van salaris voor die kapitaalkragtige ondernemer. Die kapitaalkragtige is dus in staat om pryse te laat styg, maar salarisse te laat agterbly. So plaas die kapitaalkragtige ondernemer beide die klein maatskappy en die publiek op 'n volgehoue vlak van ongelyke geleenthede, sodat hulle nie werklik in 'n bedingingsposisie verkeer ten opsigte van sy strewe na die hoogste moontlike wins nie.

Daarmee is nie gesê dat alle ongelykheid uitgeskakel kan word nie. Schumacher (1975: 234) sê:

'n Mate van ongelykheid in rykdom en inkomste is sonder twyfel 'natuurlik' en funsioneel te regverdig. Maar hier ook weer, soos in alle menslike aangeleenthede, is dit ' $\mathrm{n}$ kwessie van skaal. Oormatige rykdom, soos mag, is geneig tot korrupsie. Selfs al sou die rykes nie die 'ydel rykes' wees nie, en 
harder werk as al die ander mense, werk hulle nogtans op 'n ander manier met ' $n$ ander maatstaf, en staan hulle teenoor die geheel van die mensdom. Hulle maak hulleself korrup deur gierigheid te praktiseer, en hulle maak die res van die gemeenskap korrup deur afguns uit te lok.

- Op 'n vrye markbasis, waar daar geen direkte owerheidsinmenging en kontrole plaasvind nie, is die kapitalistiese hantering van volgehoue prysstygings - inflasie dus - deurgaans tot nadeel van die volksmassas en die klein maatskappye, en tot voordeel van die kapitaalkragtiges (wat Galbraith die 'baplanningsisteem' noem):

Die beplanningsisteem word ook min benadeel deur die ortodokse maatreëls vir die bekamping van inflasie - waarvolgens die volgehoue voorrang van die mark aanvaar word. Daar is, om te herinner, drie weë waarvolgens aanvraag dan verminder moet word - owerheidsbesteding moet ingekort word, private besteding uit geleende fondse moet ingekort word, en belasting moet verhoog word. Geeneen van hierdie raak die beplanningsisteem nie ernstig nie. Owerheidsbesteding wat produkte koop van, of direk diensbaar is aan die behoeftes van die beplanningsisteem, kan nie baie ingekort word nie. Hulle het, soos vroeër vermeld, die sanksie van 'n hoër nasionale doel - 'daar kan nie gedobbel word met die nasie se sekuriteit nie'. Gevolglik, indien afgesien moet word van uitgawes, dit uitgestel moet word of ingekort moet word om inflasie te verhinder, dan word die besnoeiing prinsipieel gedoen ten opsigte van besteding aan welsyn, behuising, stedelike dienste, onderwys en soortgelyke sake.

Daarmee is die aanvanklike impak van die beperkende begroting nie op die beplanningsisteem nie, maar op die siviele dienste van die owerheidsektor of op dié van die marksisteem... Die tweede manier om aanvraag te laat verminder is by wyse van die verhoging van rentekoerse, om daarmee die voorsiening van fondse vir die uitleen van geld te verminder.... Dit is van uiterste belang vir die beskermende doeleindes van die tegnostruktuur - die beskerming van sy outonomie - om sy afhanklikheid van geleende fondse tot die minimum te beperk. In plaas daarvan steun dit grootliks vir kapitaal op eie verdienste.... Die marksisteem, hierteenoor, steun swaar op geleende fondse. Boere sowel as die 
klein firmas onder die kleinhandelaars en winkels leen op volgehoue basis. (State, stede en onderwysdistrikte leun ook swaar op geleende fondse.) In behuising en ander konstruksiewerk is hierdie afhanklikheid bykans algeheel.

Daarby is die groot maatskappy van die beplanningsisteem, wanneer dit verplig is om te leen, ' $n$ voorkeurkliënt van die banke... . Daarom volg dit nou dat stappe om die rentekoerse te verhoog ... 'n radikaal verskillende uitwerking het op die beplannings- en marksisteme. In vergelyking word die firmas in die beplanningsisteem min geaffekteer. In die marksisteem voel hulle die volle impak van die beleid. ... Dit is lankal reeds opmerklik dat gedurende periodes van monetêre beperkings ... daar baie gekla word deur boere, die residensiële boubedryf, handelaars en ander klein sakemanne. Die groot maatskappye het dan selde klagtes... Die derde manier om aanvraag te beperk is by wyse van verhoogde belasting. Ook hier is daar' $n$ verskil in impak tussen die twee sisteme. Die beplanningsisteem het beheer oor hul pryse waar die marksisteem dit nie het nie. In dié opsig is dit in staat om hoër belasting op hulle produkte en dienste, en moontlik ook hoër belasting op hulle inkomste, oor te plaas op die koperspubliek, en hiertoe is die marksisteem nie in staat nie... (Galbraith 1974: 192-193).

Al die nadelige effekte waarvan Galbraith praat ten opsigte van ekonomiese beleid wat die groot besigheid bevoordeel ten koste van die klein firma, geld duidelik genoeg ook nadelig ten opsigte van die massa gewone mense en salaristrekkers.

Die etiese vraagstelling is: Hoe regverdig is dit?!

Milton Friedman is vandag se groot vereerder van die Klassieke Kapitalisme. Vir die 20ste eeuse aanhanger van laissez faire is hy die groot meester. Friedman is 'n voorstander van géén direkte of indirekte kontrole of regulering van die vrye markkragte van aanbod en aanvraag. Vir hom is die groot oplossing juis geleë in die volledige vrymaking van die mark, en as sulks is hy'n soort Adam Smith-redivivus. Friedman (1980: 222) sê:

Volmaaktheid is nie deel van hierdie wêreld nie. Daar sal altyd knoeiwerk, kwaksalwers en bedrieërs wees. Maar in die geheel gesien, beskerm markkompetisie, wanneer dit toegelaat word om 
te werk, die verbruiker beter as wat die alternatiewe owerheidsmeganismes wat toenemend die mark opgelê word, dit kan doen.

Die etiek het vir hom geen plek in die ekonomiese meganisme wat self sy balans uitwerk nie: 'Ons kan inderdaad nie op goedgesindheid reken vir ons maaltyd nie...' (Friedman 1980: 189).

Vir hom is dit baie belangrik dat die individu in die ekonomie konsekwent sy eie vrye keuses moet kan maak ten opsigte van wat die individu pas en die individu se begeertes tevrede stel:

Die beperkinge ingestel op ons ekonomiese vryheid dreig om twee eeue van ekonomiese vooruitgang tot 'n einde te bring ... 'n Essensiële deel van ons ekonomiese vryheid is die vryheid om te kies hoe om ons inkomste te gebruik: hoeveel te spandeer op onsself en op watter items; hoeveel om te spaar en in watter vorm; hoeveel om weg te gee en aan wie (Friedman 1980: 64-65).

Toenemende owerheidsbesteding (weens sy groeiende betrokkenheid by die welsyn en voortgang van die samelewing, en die groeiende belastinglas vir die individu wat daarmee saamgaan) sowel as die verbandhoudende owerheidsinmenging met die markmeganisme, is albei vir Friedman 'n groot bedreiging vir die vryheid van die individu.

Die dinge wat Friedman teenstaan, is dinge soos die volgende (vgl Samuelson 1976: 848), wat gewoonweg vanuit die staat geïnisieer en/of beheer word:

- Fiskale en monetêre maatreëls wat die ekonomie se opwaartse en afwaartse bewegings indirek reguleer.

- Maksimum rentekoerse.

- Minimum lone.

- Prys-en loonbeheer.

- Wetgewing om die landbou te beskerm.

- Welsyndienste en toelaes.

- Publieke dienste in die algemeen.

- Gedwonge en gratis onderwys.

- Staatsbeheer op huisstandaarde.

- Ramphulpfondse.

- Buitelandse hulpskemas.

- Voedsel- en verdowingsmiddele-wetgewing.

- Verbod op die verkope van dwelmmiddels. 
- Sentrale owerheidsbeplanning van die ekonomie.

- Beheerde wisselkoerse.

Milton Friedman se materialisme is die 20ste eeuse toonbeeld van liberalisme-kapitalisme wat laissez faire-vryheid vir die individu tot die uiterste voer in 'n konsekwente individuele vryheid om te kies (free to choose), met alleen die eweneens vrye markmeganisme om in die onbeperkte kompetisie die balans te skep en die beslissings te maak sonder dat die individu een oomblik 'n gewetensaak en 'n eties-godsdienstige kwessie daaroor hoef te maak.

Wat nie blootgestel word aan openbare konsumpsie nie, en daarom nie die nodige aandag ontvang nie, is die bevoordeling in dit alles van die kapitaalkragtige individu.

Friedman (1980: 37) se groot ideaal is '. . . 'n samelewing wat menslike vryheid bewaar en laat toeneem, wat die owerheid op sy plek hou, dit maak tot ons dienskneg en nie toelaat dat dit ons meester word nie'. ('... a society that preserves and expands human freedom, that keeps government in its place, keeping it our servant and not letting it become our master'.)

Vir Friedman is dit beslis nie ' $n$ funksie van die owerheid om instrumenteel te wees in die skepping van welvaart in almal se belang nie, maar in liberale tradisie is die owerheid basies daar om wet en orde te skep en te bewaar. Welvaart word vir hom, sonder owerheidsbemoeiing, op die ekonomiese terrein vermag in die vryheid van die individu.

Hiermee is dit duidelik dat die etiek nie werklik figureer in die meganismes van die tipiese kapitalisme nie - en juis dit is die kapitalisme se swak skakel.

\section{Literatuurverwysings}

DE GEORGE, RT \& PICHLER, JA (eds) 1978. Ethics, free enterprise, and public policy: Original essays on moral issues in business. New York: Oxford University Press.

FRIEDMAN, M 1980. Free to choose. London: Secker \& Warburg.

GALBRAITH, JK 1974. Economics and the public purpose. London: André Deutsch.

GALBRAITH, JK 1984. The anatomy of power. London: Hamish Hamilton.

SAMUELSON, PA 1976. Economics. Tokyo: McGraw-Hill Kogakusha.

SCHUMACHER, EF 1975. Small is beautiful: A study of economics as if people mattered. London: Abacus. 